\title{
Some Aspects of Antioxidative Traits in Rice Under Salinity with Validamycin Treatment
}

\author{
S. M. ${ }^{1}$ El-Khallal, Z.A.Abdelgawad ${ }^{1}$, T.A. Hathout ${ }^{1}$, E.M. \\ Said $^{2}$ and A. Z. Al Mokadem ${ }^{1}$ \\ ${ }^{1}$ Botany Department, Women's College, Ain Shams University, \\ Cairo and ${ }^{2}$ Biotechnology Lab, Horticultural Research \\ Institute, Agricultural Research Centre, Giza, Egypt
}

\begin{abstract}
D retreatment in plants is recognized as a valuable strategy to stimulate plant defenses, leading to better plant development. This study evaluated the effects of validamycin A priming pretreatment on the antioxidative mechanisms involved in the response of two rice cultivars plants to salt stress. Salt stress elevated the accumulation of hydrogen peroxide (ROS) and the endogenous Malonaldehyde (MDA). Additionally, salt stress increased the activity of antioxidative enzymes (Peroxidase, POD; Catalase, CAT; Glutathione reductase, GR). Content of phenolic compounds was also increased by salt stress, while the content of Ascorbic Acid (ASA) showed the opposite effect. Pretreatment with $30 \mu \mathrm{M}$ validamycin A as seed soaking increase the activities of superoxide dismutase, peroxidase, polyphenol oxidase, and elevate the contents of flavonoids, ascorbic acid and tocopherol. The combined effect of validamycin A and salt treatment led to a higher activity of enzymatic antioxidants including Superoxide dismutase (SOD) and GR, and elevated the content of nonenzymatic antioxidants including ascorbic acid and tocopherol. Overall, we can conclude that exogenous validamycin A could alleviate the damage induced by salt stress, via reducing the deleterious effects of salinity on lipid peroxidation. These responses could be attributed to the ability of validamycin A to induce antioxidant defenses.
\end{abstract}

Keywords: Rice, Salinity, Validamycin A, Enzymatic antioxidant, Non enzymatic antioxidant

Plant responses to salt stress have generally been conducted using anatomical, ecological, physiological, and molecular approaches (Lee et al., 2013) in relation to regulatory mechanisms of ionic and osmotic homeostasis. Moreover, salt stress, like other abiotic stresses, results in oxidative stress through an increase in reactive oxygen species (ROS), such as superoxide radical $\left(\mathrm{O}_{2}^{--}\right)$, hydrogen peroxide $\left(\mathrm{H}_{2} \mathrm{O}_{2}\right)$, and the hydroxyl radical $\left(\mathrm{OH}^{-}\right)$. These ROS are highly reactive, altering normal cellular metabolism through oxidative damage to lipids, proteins, and nucleic acids (Adly, 2010). In addition, salt adversely affects the metabolism of plants, resulting in substantial modifications in plant gene expression. These modifications may lead to the accumulation or depletion of certain metabolites, resulting in an imbalance in the levels of cellular proteins, which may increase, decrease, appear, or disappear after salt treatment (Lee et al., 2013). 
Trehalose is a non-reducing disaccharide that occurs in a large range of organisms and functions in the regulation of carbohydrate metabolism, as stress protection metabolite and storage carbohydrate (Eastmond and Graham, 2003 and Paul, 2007). Recently, there is a focus of interest on the role of trehalose as it improves the performance of plants under drought, nutrition element deficiency or toxicity or salinity (Chang et al., 2014a). The underlying mechanism by which trehalose improves plant response to salinity, and other adverse environmental factors, is still unclear (Paul et al., 2008). For example, it is suggested that trehalose function through its ability to scavenge reactive oxygen species, conferring protection to the machinery of protein synthesis (Chang et al., 2014b).

In plants, trehalose is formed from UDP-glucose and glucose-6 phosphate and catalyzed by the enzyme trehalose-6-phosphate synthase (TPS). Subsequently, this is dephosphorylated into trehalose by the enzyme trehalose-6phosphate phosphatase (TPP). Furthermore, trehalase, the key enzyme responsible for the hydrolysis of trehalose during degradation, is present in all organs of higher plants (Schluepmann and Paul, 2009). Exogenous validamycin A (trehalase inhibitor) treatment decreased the activity of trehalase which leads to the accumulation of trehalose in shoots and roots of wheat plants. Raising trehalose level in the plant tissues was accompanied by increase in the sucrose content and starch content of the shoot (Ahmed et al., 2013). Validamycin A also induced an increase in trehalose concentration in root nodules of Medicago truncatula by inhibiting trehalase activity, which then improved the response to salinity by increasing plant dry weight (Lo'pez et al., 2009). Finally, validamycin A increased foliar cellulose and starch content and decreased total amino acid, and nitrate content of mature tobacco plants (Best et al., 2011). Consequently, it should be possible to direct increased trehalose accumulation by down regulating plant trehalase activity or by expressing the trehalose biosynthetic genes under tissue- or stress specific regulation. The objective of this work is to study the possible roles of exogenous trehalase inhibitor validamycin $\mathrm{A}(30 \mu \mathrm{M})$, on alleviating the harmful effects of salt stress on antioxidant compounds.

\section{Material and Methods}

\section{Plant and chemical materials}

Two cultivars of rice (Orizasativa L.)Sakha 103 and Agami M5 cultivar were obtained from Agricultural Research Centre, Ministry of Agriculture, Giza, Egypt. Validamycin A was provided by Qianjiang Biochem. Co. Ltd., China and other chemicals were purchased from Sigma and Fisher group.

\section{Methods}

Seeds of both rice cultivars were surface sterilized with a $5 \%$ sodium hypochlorite solution for $5 \mathrm{~min}$. After washing several times with distilled water, seeds were imbibed in Petri-dishes containing distilled water in a culture room at $24 \pm 2{ }^{\circ} \mathrm{C}$ until the appearance of the white tip of the coleoptile. After imbibitions, the seeds of each genotype were divided into two groups.

Egypt. J. Bot., Vol. 56, No. 1 (2016) 
Seeds of the $1^{\text {st }}$ group were left in distilled water without any treatments (control). Seeds of the $2^{\text {nd }}$ group were soaked in $30 \mu \mathrm{M}$ validamycin A (Lo'pez et al., 2009) for $8 \mathrm{hr}$.Then the seeds of both treatments were planted in plastic pots (diameter $30 \mathrm{~cm}$ and $40 \mathrm{~cm}$ depth) with split plot design, each pot contained $7 \mathrm{~kg}$ sandy loam soil. Soil characteristics were: sand $84.2 \%$, silt $12.9 \%$, clay $2.9 \%, \mathrm{pH} 7.7, \mathrm{EC} 0.5 \mathrm{dSm}^{-1}$ and organic matter $1.2 \%$. Each pot contained ten plants; the seedlings were irrigated with tap water for 14 days under normal conditions.

\section{Salt Stress treatment}

Fourteen days old seedlings of the $1^{\text {st }}$ and the $2^{\text {nd }}$ groups from both cultivars of rice plants were subjected to salt stress $(0,50,75,100 \mathrm{mM} \mathrm{NaCl})$ (Sawada et al., 2006) for 2 weeks period. Preliminary experiments showed that $\mathrm{NaCl}$ treatment more than $100 \mathrm{mM}$ caused damage too severe to investigate biological response. Phenotypic analysis was developed at 21 and 28 days old plants after stress conditions.

\section{Plant sampling for analysis}

Plants were harvested at two times (21 and 28 day after planting). The roots were discarded from the plant shoot system before backing in aluminum foil. Each packet of aluminum foil was then immediately frozen in liquid nitrogen and stored in a $-80^{\circ} \mathrm{C}$ freezer until using for various biochemical analyses.

\section{Physiological and Biochemical Analysis}

Determination of oxidative damage

Hydrogen peroxide level was determined according to (Sergievet al., 1997), level of lipid peroxidation was measured according to (Heath and Packer, 1968).

\section{Antioxidant system extraction and assay}

Antioxidant enzymes activity

Extraction was done as reported by Silvanaet al. (2003). Superoxide dismutase (SOD; EC 1.15.1.1) activity was measured (Giannopolitis and Ries, 1977). Catalase (EC 1.11.1.6) assay method was that adopted by Aebi (1984). Catalase activity was estimated spectrophotometrically at $240 \mathrm{~nm}$ using JENWAY $6305 \mathrm{UV} / \mathrm{VIS}$ and the activity was expressed as mmol $\mathrm{H}_{2} \mathrm{O}_{2}$ decomposed $\mathrm{min}^{-1} \mathrm{~g}^{-1} \mathrm{FW}$ (Yingsanga et al., 2008). Ascorbate peroxidase (APX; EC 1.11.1.11) activity was determined (Yingsanga et al., 2008), Glutathione reductase (GR, EC 1.6.4.2) was assayed according to Hodges et al. (1997) method with some modification (Yingsangaet al., 2008). Peroxidase (POD, EC1.11.1.7) activity was measured (Yingsanga et al., 2008). Polyphenol oxidase (PPO; EC 1.30.3.1) enzyme assay as reported by Yingsanga et al. (2008).

\section{Isozymes extraction and assay}

The following three isozyme systems have been studied: peroxidase (POD), Superoxide dismutase (SOD) and polyphenol oxidase (PPO). Isozymes were extracted from plant ground samples according to Yamunarani et al. (2004). Peroxidaseisozyme assay by $12 \%$ native polyacrylamide gel electrophoresis 
(PAGE) analysis according to Yamunarani et al. (2004). SOD was localized on $10 \%$ native gel using photochemical method of Beauchamp and Fridovich (1971). Native electrophoresis was performed with PPO crude extracts according to the method of Laemmli (1970) without SDS and 10\% polyacrylamide gels.

Native PAGE and localization of enzymes on polyacrylamide gels

Polyacrylamide gel electrophoresis was carried out for separation of different enzyme isoforms using discontinuous gel under non denaturing condition essentially as described by Hames (1990). Ten percent or $12.0 \%$ native gels were prepared and run at constant potential $(200 \mathrm{~V})$ and current $(30 \mathrm{~mA})$ at $4.0^{\circ} \mathrm{C}$ using a discontinuous buffer system as described by Hames (1990).

\section{Antioxidant compounds extraction and determination}

Total phenolic in rice tissues was appraised following the method of Julkenen-Titto (1985). The OD was read at $750 \mathrm{~nm}$, using a UV-Visible spectrophotometer (JENWAY 6305 UV/VIS), Total flavonoids was extracted from rice tissue according to Lee and Wicker (1991). Total flavonoids content was determined following Yong et al. (2008). Ascorbic acid was measured as described by Jagota and Dani (1982).Tocopherol content was assayed as described (Backer et al., 1980).

\section{Statistical analysis}

The obtained data were treated statistically using the one-way analysis of variance as described by Snedecor and Cochran (1969) .Means were compared by LSD at $5 \%$ using SPSS program version 16.

\section{Results}

\section{Production of Reactive Oxygen Species (ROS)}

Hydrogen Peroxide Levels

A rapid production of reactive oxygen species is one of the earliest detectable responses to stress in plant cells and is an indicator to the activity of potential inducers. Results in Fig. 1. appeared that hydrogen peroxide levels in both rice cultivars increased significantly with increasing the $\mathrm{NaCl}$ concentration at 21 and 28 days old treated plants in comparison with the control. The magnitude of increase was at $100 \mathrm{mM}$ at 28 days old plants in Sakha103 cultivar. Treatments with validamycin $A$, increased the levels of $\mathrm{H}_{2} \mathrm{O}_{2}$ in non saline plants in both cultivars especially in Sakha103 cultivar as compared with untreated control. While salinized plants treated with validamycin A showed a decrease in the level of $\mathrm{H}_{2} \mathrm{O}_{2}$ in both cultivars when compared with their corresponding salinity levels. Suppression in $\mathrm{H}_{2} \mathrm{O}_{2}$ accumulated levels with laps of time in Agami M5 cultivar treated with salt plus validamycin A was recorded.

\section{Lipid Peroxidation}

The increase in level of metabolite scavenging reactive oxygen species and antioxidant enzyme activity may be linked to the changes in lipid peroxidation. 
Therefore, results in Fig. 2 showed that the content of lipid peroxides, measured as malondialdehyde (MDA) concentration, the cytotoxic product of lipid peroxidation, was increased gradually in respect to the applied salt concentration. The most pronounced effect occurred in Sakha103 and Agami M5 after 21 days old in response to $100 \mathrm{mM} \mathrm{NaCl}$. The plants supplied with validamycin A produced the highest MDA content in AgamiM5 cultivar in comparison with the control. On the other hand, the levels of MDA significantly decreased in both rice cultivars soaked by validamycin A and treated with salt stress as compared with untreated control after 21days old. After 28 days from salt application, MDA content decreased more than after 21days in Agami M5, while it increased in Sakha103 plants.

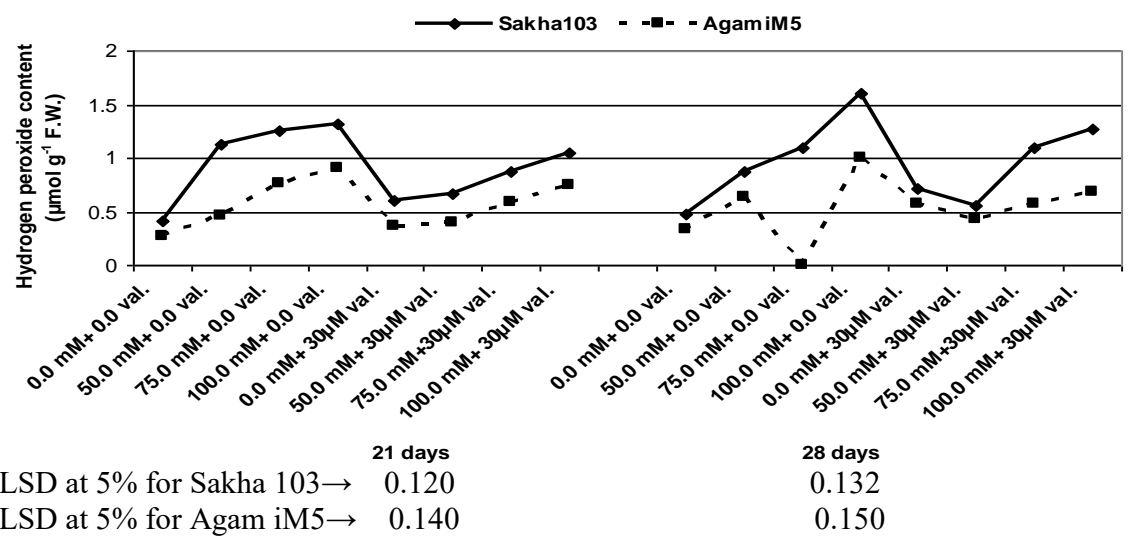

Fig. 1. Production of hydrogen peroxide content $\left(\mu \mathrm{mol} \mathrm{g}^{-1}\right.$ F.W.) in tissues of two rice cultivars treated with $30 \mu \mathrm{M}$ validamycin $A$ and grown under different conc. of $\mathrm{NaCl}$.

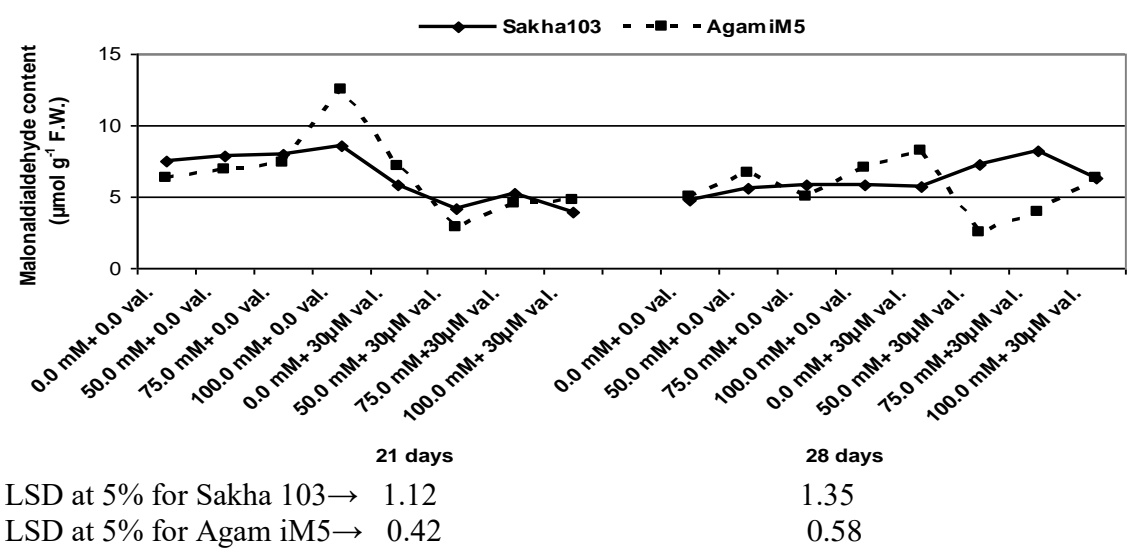

Fig. 2. Production of malonaldialdehyde content ( $\mu$ mol $\mathrm{g}^{-1}$ F.W.) in tissues of two rice cultivars treated with $30 \mu \mathrm{M}$ validamycin $\mathrm{A}$ and grown under different conc. of $\mathrm{NaCl}$. 
Activity of antioxidant enzymes

Enzymatic ROS scavenging mechanisms in plants were assayed in plant tissues of rice cultivars treated with validamycin A and grown under salt stress. Activity of SOD, CAT, APX, GR, POD and PPO were recorded in Figure 3, 4, $5,6,7$ and 8 , respectively.

\section{Superoxide dismutase Activity}

SODs act as the first line of defense against ROS, dismutating superoxide $\mathrm{O}^{2 \text { - }}$ to $\mathrm{H}_{2} \mathrm{O}_{2}$. APX, GR and CAT subsequently detoxify ROS. Activity of SOD increased with different concentrations in both Sakha103 and Agami M5 at 21 and 28 days old as compared with control (Fig. 3). At $75 \mathrm{mMNaCl}$ both cultivars showed the highest activity of $\mathrm{NaCl}$ which increased from 64.2 to 76.4 ( $\mathrm{U} \mathrm{min}^{-1} \mathrm{~g}^{-1}$ F.W.) in Sakha103 and from 73.18 to 85.88 (U min $\mathrm{g}^{-1}$ F.W.) in Agami M5 plants of 21 days old. On the other hand, results in Fig. 3 show that validamycin A treatment increased activity of SOD in both cultivars tissues comparing with the control. The highest activity (87.9 $\mathrm{U} \mathrm{min}^{-1} \mathrm{~g}^{-1}$ F.W.) was found in Agami M5 of 21 days old plants treated with validamycin $\mathrm{A}$ and $100 \mathrm{mM} \mathrm{NaCl}$.

\section{Catalase Activity}

As shown in Fig. 4 application of 50, 75 and $100 \mathrm{mM} \mathrm{NaCl}$ increased catalase (CAT) activity in both cultivars at both exposure periods in respect to control, which may have been induced by the increased $\mathrm{H}_{2} \mathrm{O}_{2}$ resulting from SOD activity and the activity of CAT in Sakha103 cultivar was higher than that in AgamiM5. On the other hand, application of validamycin $\mathrm{A}(30 \mu \mathrm{M})$ as seed soaking induced an additive at 21days old, meanwhile, at 28 days old the activity of Agami M5 was higher especially at high concentrations of $\mathrm{NaCl}$ levels stimulatory effect on the CAT activity as compared with those of the untreated control in both cultivars. Significant reductions in CAT activity were observed in both cultivars under $50 \mathrm{mM}$ $\mathrm{NaCl}$ in comparison to the control plants and the corresponding salinity levels. Under 75 and $100 \mathrm{mM} \mathrm{NaCl}$ pretreated with validamycin A, the CAT activity increased significantly in plant tissues of both cultivars, but in Agami M5, at 21days old at all treatments were less than the corresponding control.

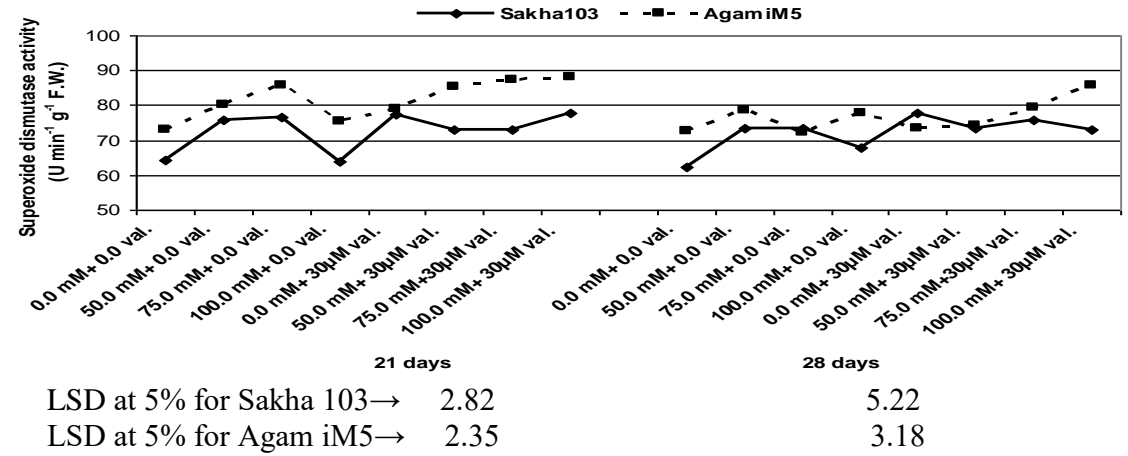

Fig. 3. Superoxide dismutase activity $\left(U \mathrm{~min}^{-1} \mathrm{~g}^{-1} \mathrm{~F}\right.$.W. $)$ in tissues of two rice cultivars treated with $30 \mu \mathrm{M}$ validamycin $\mathrm{A}$ and grown under different conc. of $\mathrm{NaCl}$.

Egypt. J. Bot., Vol. 56, No. 1 (2016) 


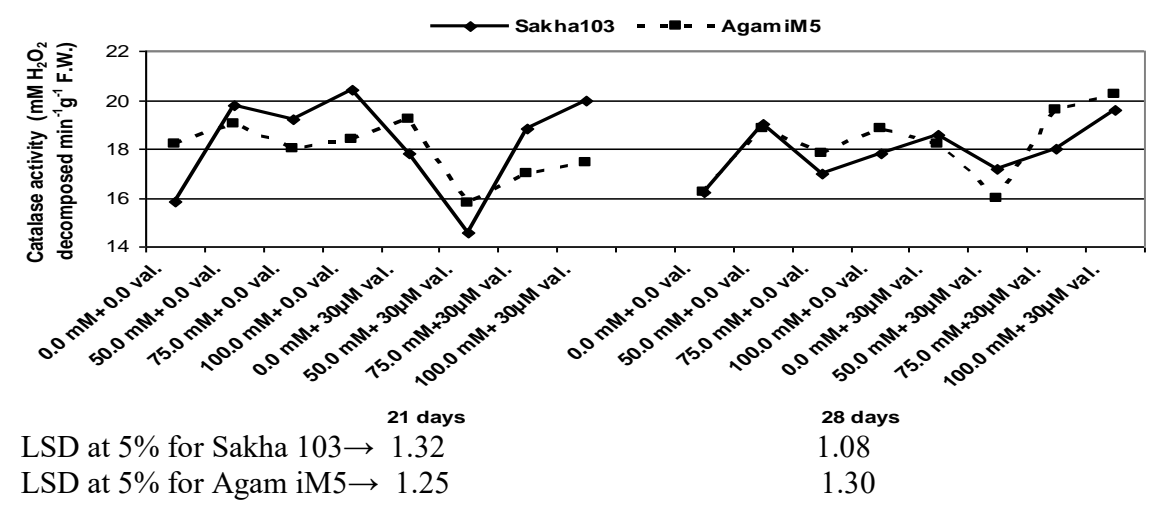

Fig. 4. Catalase activity ( $\mathrm{mM} \mathrm{H} \mathrm{H}_{2} \mathrm{O}_{2}$ decomposed $\min ^{-1} \mathrm{~g}^{-1}$ F.W.) in the tissues of two rice cultivars treated with $30 \mu \mathrm{M}$ validamycin $\mathrm{A}$ and grown under different conc. of $\mathrm{NaCl}$.

\section{Ascorbate Peroxidase Activity}

Ascorbate peroxidase (APX) share crucially in the detoxification of $\mathrm{H}_{2} \mathrm{O}_{2}$, according to the following reaction: 2 ascorbate $+\mathrm{H}_{2} \mathrm{O}_{2} \rightarrow 2$ monodehydroascorbate $+2 \mathrm{H}_{2} \mathrm{O}$.

Figure 5 show that activity of APX significantly increased in both rice cultivars treated by $\mathrm{NaCl}$ concentrations as the compared with non-treated control. Activity of APX in Sakha103 was higher than that in Agami M5 at 21days old plants of all treatments and increased with increasing the concentration in both cultivars but at 28 days old was decreased in Sakha103 while increased in Agami M5. Validamycin A increased activity of APX in both salt sensitive and tolerance cultivars under salt stress as compared with corresponding salinity level except in salt sensitive plants at 21days old different, where validamycin A treatments decreased APX activity as compared with the untreated control. At the same conditions, the maximum activity was found in Agami M5-treated with validamycin A plus $75 \mathrm{mM} \mathrm{NaCl}$ at 28 days old plants.

Glutathione Reductase Activity: Glutathione reductase (GR) activity in AgamiM5 of salt-stressed plants was greater than control plants after 21 and 28 days from treatment and increased with increasing the salt concentration at 21 days old plants (Fig. 6). The highest GR activity was observed at $100 \mathrm{mM} \mathrm{NaCl}-$ treated plants at 21 days old. On the other hand, $50 \mathrm{mM} \mathrm{NaCl}$ caused a slight increase in GR activity in Sakha103 CV (Fig. 6). However, $\mathrm{NaCl}$ at $75 \mathrm{mM}$ and $100 \mathrm{mM}$ in salt-sensitive Sakha103 reduced GR activity of the two stages of growth. Pretreatment of both rice seed cultivars with validamycin A induced significant increases in GR activity of salt stressed-rice plant as compared with their corresponding salinity levels. The basal level of GR activity was also higher in AgamiM5 (647.91 $\mu \mathrm{M}$ NADPH oxidized $\min ^{-1} \mathrm{~g}^{-1}$ F.W.) than in Sakha103 (514.5 $\mu$ M NADPH oxidized min $^{-1} \mathrm{~g}^{-1}$ F.W.) as shown in Fig. 6. 
Peroxidase Activity: The activity of peroxidase enzyme significantly decreased in Sakha103 cultivar of 21days old plants in response to the application of $\mathrm{NaCl}$ by 50 and $75 \mathrm{mM}$, but $100 \mathrm{Mm}$ caused a slight increase as compared with non-treated control (Fig. 7). In Agami M5 POD activity increased with increasing the concentration of salt application and reached to maximum activity in plants of 21days old plants treated by $100 \mathrm{mM} \mathrm{NaCl}$, but in the 28 days old plants the activity was declined in stressed and non stressed line in meantime the stressed plants was more than the non-stressed in value.

Also, data cleared that pretreatment with validamycin $(30 \mu \mathrm{M})$ in response of salt stress induced significant increases in Agami M5 cultivar at 21 days old of salt application as compared with corresponding salinity level. On the other hand, in Sakha103 the POD activity was lower than the corresponding salinity level of 21 and 28 old day plants.

Polyphenol oxidase Activity: Polyphenol oxidase (PPO) activity in salt tolerant cultivar increased significantly with increasing $\mathrm{NaCl}$ concentrations at 21 and 28 days old compared to the control and the highest PPO activity observed at $100 \mathrm{mMNaCl}$ concentration at 28 days old treated plant (Fig. 8). However, PPO activity of Sakha103 was increased under lower levels of salt treatment, while it was decreased under highest exerted levels of them compared to control.

Results of both cultivars showed that, PPO activity increased in all treatments as compares with corresponding control at 21 and 28 days old plants.

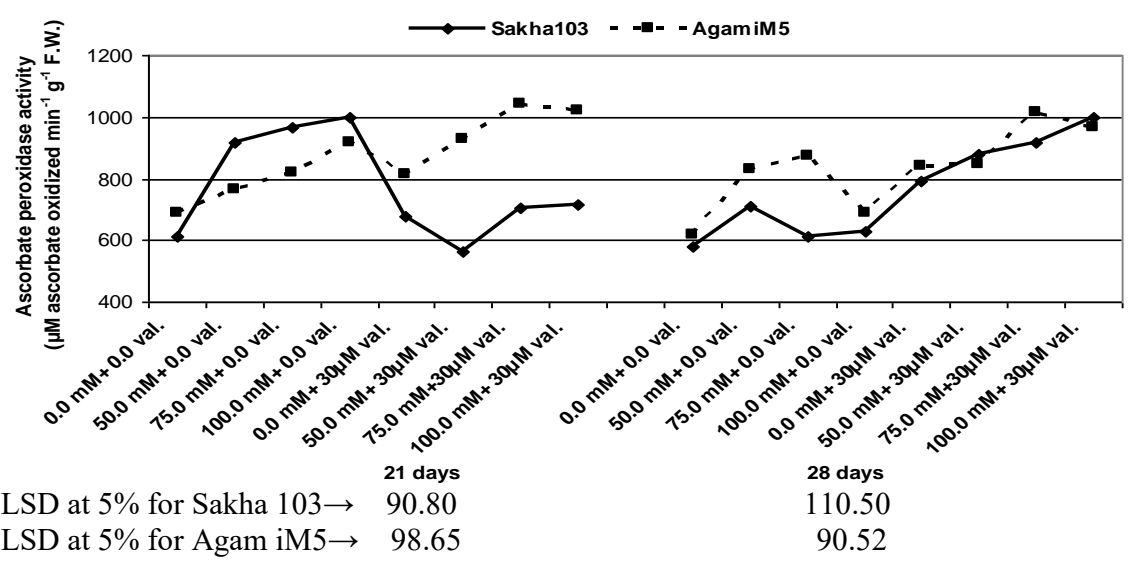

Fig. 5. Ascorbate peroxidase activity ( $\mu \mathrm{M}$ ascorbate oxidized $\min ^{-1} \mathrm{~g}^{-1} \mathrm{~F}$.W.) in tissues of two rice cultivars treated with $30 \mu \mathrm{M}$ validamycin $\mathrm{A}$ and grown under different conc. of $\mathrm{NaCl}$. 


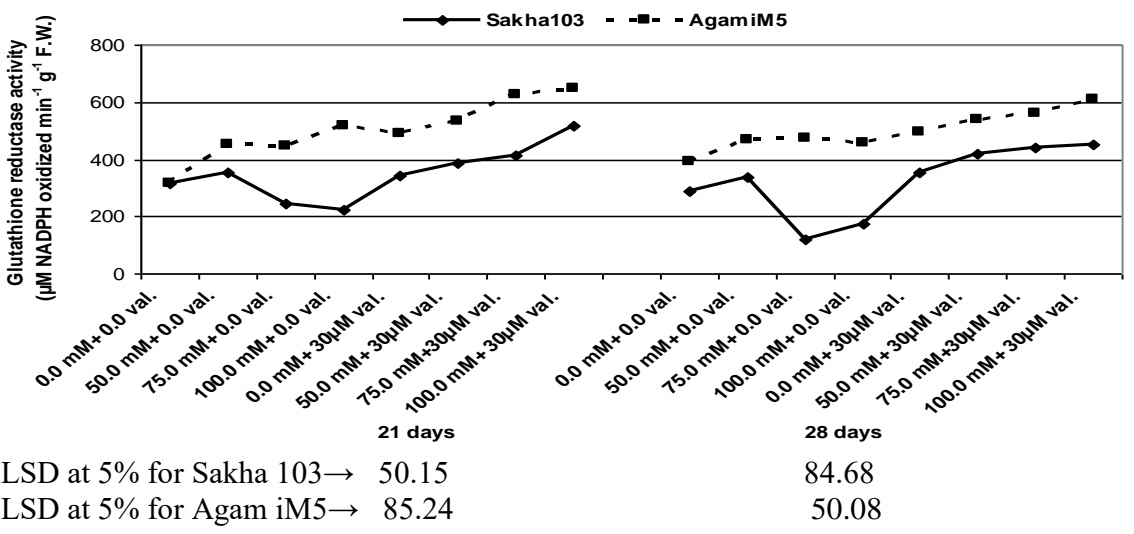

Fig. 6. Glutathione reductase activity ( $\mu M$ NADPH oxidized $\min ^{-1} \mathrm{~g}^{-1}$ F.W.) in the tissues of two rice cultivars treated with $30 \mu \mathrm{M}$ validamycin $\mathrm{A}$ and grown under different conc. of $\mathrm{NaCl}$.

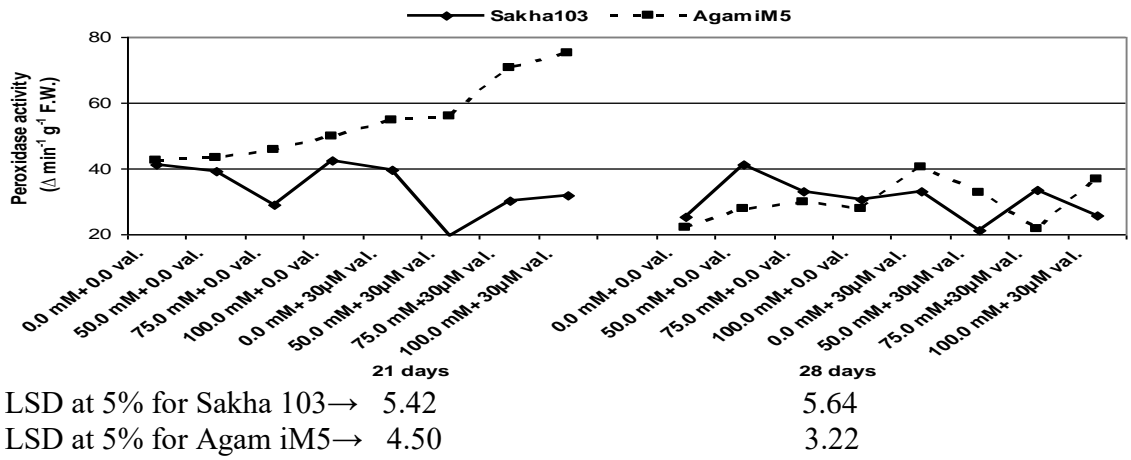

Fig. 7. Peroxidase activity $\left(\Delta \min ^{-1} \mathrm{~g}^{-1}\right.$ F.W. $)$ in the tissues of two rice cultivars treated with $30 \mu \mathrm{M}$ validamycin $\mathrm{A}$ and grown under different conc. of $\mathrm{NaCl}$.

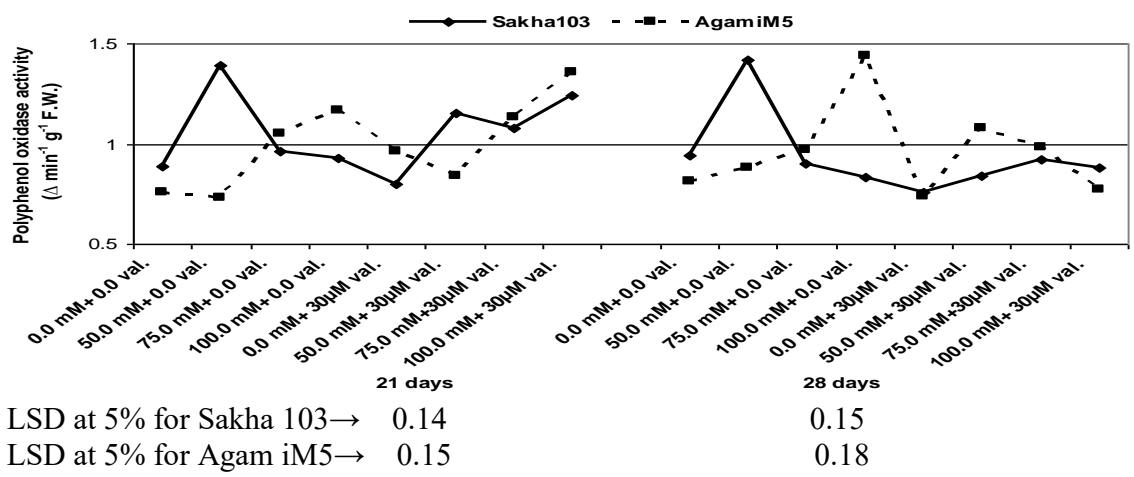

Fig. 8. Polyphenol oxidase activity $\left(\Delta \min ^{-1} \mathrm{~g}^{-1} \mathrm{~F} . \mathrm{W}\right)$ in tissues of two rice cultivars treated with $30 \mu \mathrm{M}$ validamycin $\mathrm{A}$ and grown under different conc. of $\mathrm{NaCl}$. 
Biochemical analysis: Isozyme profile

Superoxide dismutase isozyme

Three isozymes of SOD (Mn-SOD, Fe-SOD, and Cu/Zn-SOD) were recorded at Rf $0.409,0.72$ and 0.799 . The overall activity of the enzymes was higher in both cultivars treated with $\mathrm{NaCl}$ and/or validamycinA on gel as evidenced by the brighter bands. The intensity levels of SOD isozyme in leaves of salt treatment plus validamycin A was higher than that of salt stress in both cultivars (Photo 1 $\mathrm{a}, \mathrm{b})$. The intensities of the Mn-SOD isoform remained similar to response in both cultivars, whereas $\mathrm{Cu} / \mathrm{Zn}$ SOD and Fe-SOD were more intense with all concentrations of $\mathrm{NaCl}$ alone and with combination with validamycin $\mathrm{A}$.

\section{Peroxidase isozyme}

In the leaves of both rice cultivars, five isoforms bands of POD were observed ranging in RF from 0.05 to 0.845 (Photo $1 \mathrm{c}$, d). In AgamiM5 cultivar, the five POD isoforms intensity in the plant tissues increased with increasing $\mathrm{NaCl}$ concentration. The higher intensity was found in plants primed with validamycin A plus salt stress (Photo $1 \mathrm{c}$, d). On the other hand, in Sakha103 cultivar, the intensity was decreased after $\mathrm{NaCl}$ application and increased in plants treated with salt stress plus validamycin A. The exhibition intensity of both band POD-3 and POD-4 was obviously higher than the other bands in the respective validamycin A treatment of both cultivars, indicating that POD-3 and POD-4 were the dominant POD isoforms with regard to band exhibitions.

\section{Polyphenol oxidase isozyme}

There were five bands of PPO as visualized in RF ranging from 0.077-0.506 (Photo $1 \mathrm{e}, \mathrm{f}$ ). The PPO-4 and PPO-5 which was the most prominent isoform in intensity, greatly increased in the level of intensity in 50 and $75 \mathrm{mM} \mathrm{NaCl}$ plus Validamycin A treatments in both cultivars compared to the 50 and $75 \mathrm{mM} \mathrm{NaCl}$ treatments alone (Photo $1 \mathrm{e}, \mathrm{f}$ ).

\section{Antioxidant compounds}

Total Phenols

The effect of $\mathrm{NaCl}$ on total phenols is shown in Fig. 9. Total phenol content in both rice cultivars was significantly increased gradually with increasing the salinity level. $\mathrm{NaCl}$ at $100 \mathrm{mM}$ gave the highest content of total phenol which was 2.3 to 2.8 folds and 2.8 to 3.1 folds in Sakha103 and Agami M5, respectively at 21 and 28 days old treated plants, higher than control. The increament in phenols in rice plants under salinity stress is reduced with priming seeds of two cultivars in validamycin.

\section{Total Flavonoids Content}

At 21 days old treated plants, total flavonoids increased gradually with increasing salt concentration in both cultivars as compared with control plants (Fig. 10). Prolonged application with $\mathrm{NaCl}$ concentrations caused decrease of the total flavonoid content. On the other hand, application of $\mathrm{NaCl}$ concentrations increased content of flavonoids in validamycin A treated plants as compared to the corresponding salinity level. The maximum increase was at $75 \mathrm{mM} \mathrm{NaCl}$

Egypt. J. Bot., Vol. 56, No. 1 (2016) 
concentration in Sakha103 and Agami M5 which increased by $84.4 \%$ and $88.2 \%$ respectively at 21 days old.

Salt application at different concentrations significantly increased flavonoid content in Sakha103 and Agami M5 plants treated with validamycin A at 28 days old when compared with that treated or/and untreated with validamycin A and all values were more than the corresponding salinity level.

Ascorbic Acid content: Data in Fig. 11 appeared that salt stress significantly reduced ascorbic acid (ASA) contents of both cultivars. ASA decreased gradually by increasing $\mathrm{NaCl}$ concentrations compared with control. The maximum reduction was at $100 \mathrm{mM} \mathrm{NaCl}$ and reached $46.0 \%, 43.9 \%$ in Sakha103 and to $44.9 \%$ and $43.6 \%$ in AgamiM5 at 21 and 28 old days, respectively as compared with non-treated plants. Agami M5 maintained significantly higher ASA content under control and salt stress on whole tissue basis. Priming of both rice seeds with validamycin A improve stress resistance by increasing the content of ASA as compared with corresponding salinity level. The highest increase in ASA was $34.12 \%$ and $15.0 \%$ in Sakha103 and Agami $\mathrm{M} 5$, respectively, treated with $50 \mathrm{mM} \mathrm{NaCl}$ at 28 days old.

$\alpha$-tocopherol content: In AgamiM5 rice plants, $\alpha$-tocopherol increased with increasing concentration of $\mathrm{NaCl}(12.3 \%$ at $50 \mathrm{mM}$ and $16.3 \%$ at $75 \mathrm{mM} \mathrm{NaCl})$ at 21 days old. Although, $\alpha$-tocopherol decreased with the further increase of $\mathrm{NaCl}(100 \mathrm{mM})$, it still remained higher (by $4.31 \%)$ than in the untreated control (without $\mathrm{NaCl}$ ) plants (Fig. 12). The highest $\alpha$-tocopherol content was observed at $75 \mathrm{mM} \mathrm{NaCl}$-treated plants $(27.9 \%)$ at 28 days old. On the other hand, $\alpha$ tocopherol in plant tissues of Sakha103 cultivar (salt sensitive) was increased under lower levels of salt treatment, while it was decreased under highest levels compared to control in the two stages of salt treatments.

Pretreatment of both rice seed cultivars with validamycin A $(30 \mu \mathrm{M})$ induced significant increases in $\alpha$-tocopherol content of rice plant under non stressed and all salinity levels as compared with the corresponding salinity level. Significantly higher values of $\alpha$ - tocopherol contents were observed in Agami M5 as compared to those in cv. Sakha103. In Agami M5 cultivar, the highest $\alpha$ tocopherol content was observed at $100 \mathrm{mM} \mathrm{NaCl}$-treated validamycin A plants reached $56.1 \%$ over the control in 28 days old plants. However, in Sakha103 the maximum increase was recorded at $75 \mathrm{mM} \mathrm{NaCl}$-treated plants reached $36.6 \%$ over the control in 28 days old plants. 


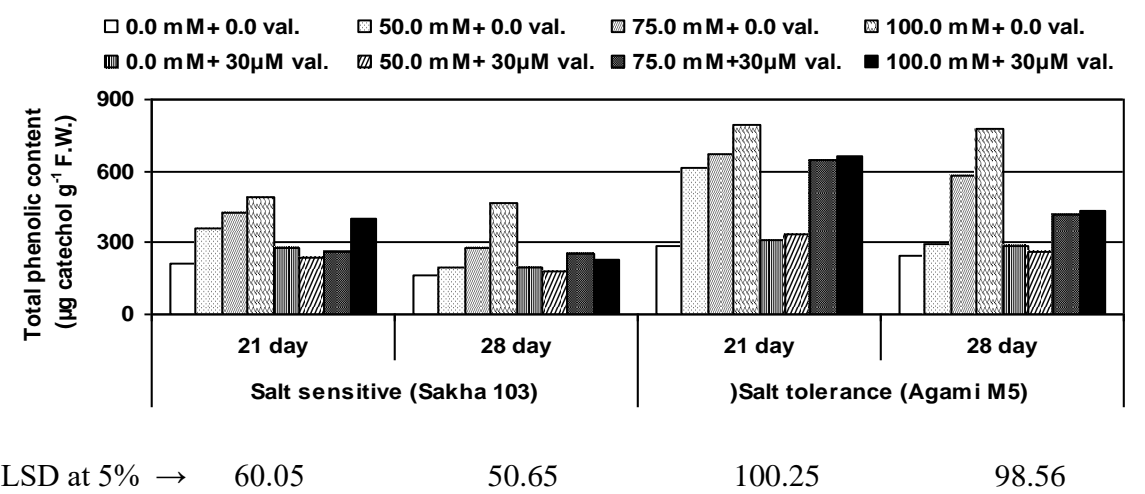

Fig. 9. Change in total phenolic content $\left(\mu \mathrm{g}\right.$ catechol $\mathrm{g}^{-1} \mathrm{~F}$.W.) in shoots of two rice cultivars treated with $30 \mu \mathrm{M}$ Validamycin $A$ andgrown under different conc. of $\mathrm{NaCl}$.

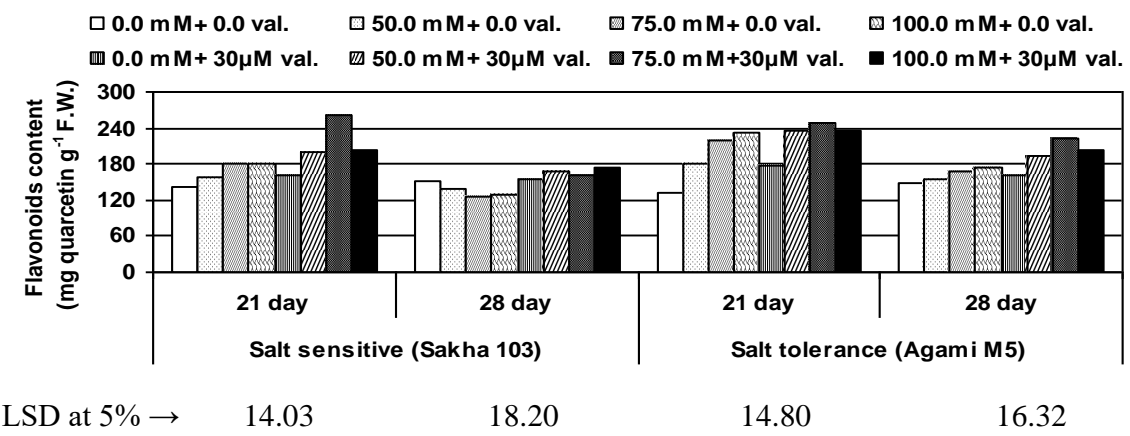

Fig. 10. Change in total flavonoids content (mg quarcetin $\mathrm{g}^{-1} \mathrm{~F}$.W.) in shoots of two rice cultivars treated with $30 \mu \mathrm{M}$ Validamycin $A$ andgrown under different conc. of $\mathrm{NaCl}$.

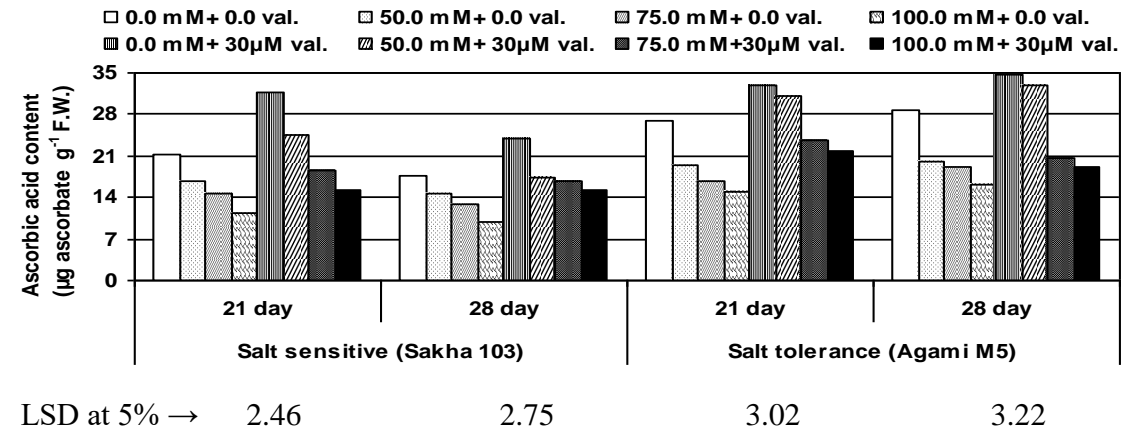

Fig. 11. Change in ascorbic acid content ( $\mu$ g ascorbate $\mathrm{g}^{-1} \mathrm{~F}$. W.) in shoots of two rice cultivars treated with $30 \mu \mathrm{M}$ Validamycin $A$ andgrown under different conc. of $\mathrm{NaCl}$.

Egypt. J. Bot., Vol. 56, No. 1 (2016) 


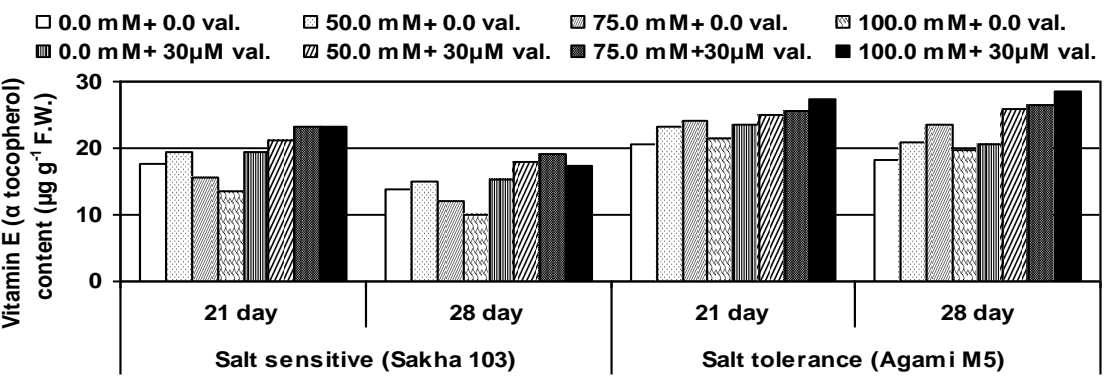
LSD at $5 \% \rightarrow$
2.08
2.10
2.11
1.85

Fig. 12. Change in vitamin $E$ ( $\alpha$ tocopherol) content ( $\mu \mathrm{g} \mathrm{g}^{-1} \mathrm{~F} . \mathrm{W}$.) in shoots of two rice cultivars treated with $30 \mu \mathrm{M}$ Validamycin $A$ andgrown under different conc. of NaCl.

(a)

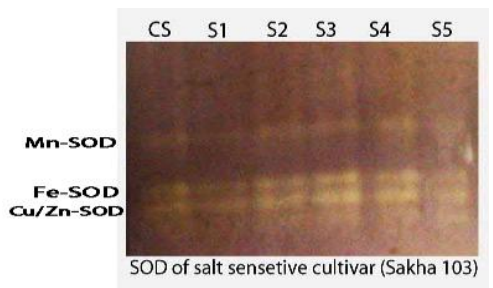

(c)

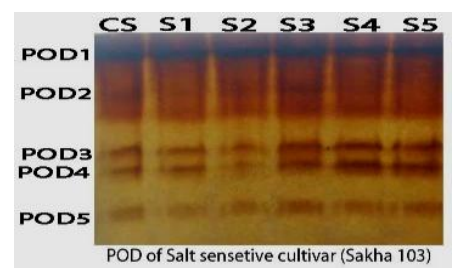

(e)

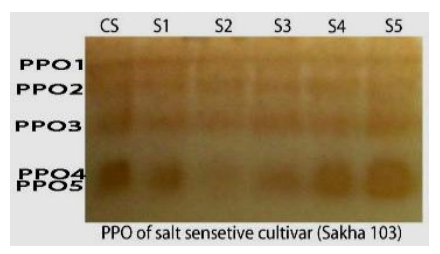

(b)

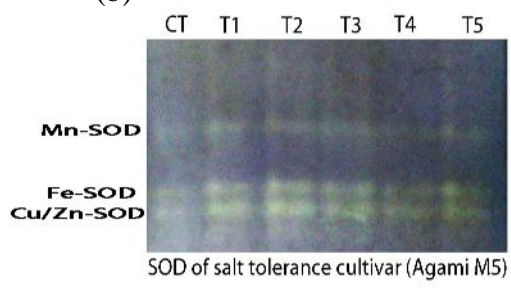

(d)

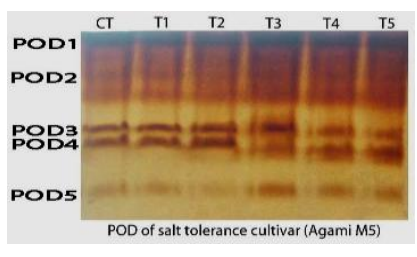

(f)

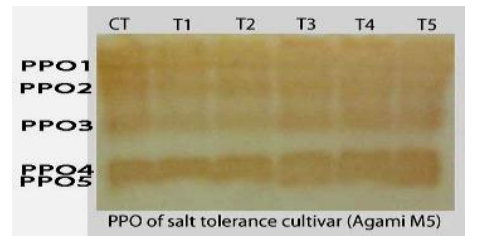

Photo 1. Electrophoretic patterns of superoxide dismutase (a), (b), peroxidase (c),(d) and polyphenol oxidase (e),(f) isoenzyme of salt sensetive (Sakha 103)and salt tolerance (Agami M5) rice cultivars in response to treatment with different concentrations of $\mathrm{NaCl}$ alone or in combination with $30 \mu \mathrm{M}$ validamycin $\mathrm{A}$.

cs, ct-Control; S1,T1-50 mM NaCl; S2,T2- 75 mM NaCl; S3,T4- validamycin A only; S4,T4$50 \mathrm{mM} \mathrm{NaCl}+$ validamycin A; S5,T5- $75 \mathrm{mM} \mathrm{NaCl}$ +validamycin A. 


\section{Discussion}

Increased tolerance to abiotic stress in crop plants is necessary in order to increase the plant productivity under limited water supplies, high salinity and low temperature. Tolerant genotypes respond to abiotic stress with complex changes in their physiological and molecular status. Differential responses of different genotypes of a common species to abiotic stresses imply that mechanisms conveying tolerance differ between genotypes and stresses (Morsy et al., 2007).

Salt stress can induce oxidative stress due to generation of reactive oxygen species (ROS), including singlet oxygen, superoxide anion, hydrogen peroxide and hydroxyl radical (Malik et al., 2011). ROS attack the cellular macromolecules, such as proteins, nucleic acids and membrane lipids causing their damage (Mansour, 2013).

$\mathrm{H}_{2} \mathrm{O}_{2}$ is one of the active oxygen species and produced by the action of SOD (Cheeseman, 2007). The $\mathrm{H}_{2} \mathrm{O}_{2}$ content showed a progressive increase in salt-treated rice plants, particularly in salt-sensitive cultivars (Tsai et al., 2004). Our results demonstrated that the level of $\mathrm{H}_{2} \mathrm{O}_{2}$ in leaves of both rice cultivars significantly increased with $\mathrm{NaCl}$ stress and validamycin A had a smaller stimulative effect when compared to the control plants. Hernandez et al. (2010) suggesting that the accumulation of $\mathrm{H}_{2} \mathrm{O}_{2}$ at short-term salt stress is mainly due to the osmotic stress induced by the external $\mathrm{NaCl}$. Lower level of the $\mathrm{H}_{2} \mathrm{O}_{2}$ for salt-tolerant genotype (AgamiM5) versus salt-sensitive ones under salt stress might be attributed to the relatively more efficient detoxifying enzymes CAT, POD and APX.

The generation of ROS was alleviated by application of validamycin A which increase trehalose content under salt stress. Similar results were reported in wheat seedlings exposed to heat stress (Luo et al., 2008). Both trehalose-producing transgenic plant and exogenous application could reduce generation of ROS, but it would affect the subsequent plant defense response (Fernandez et al., 2010).

To investigate whether trehalose-induced membrane protection is accomplished by preventing lipid peroxidation, we detected the MDA content, which is produced when polyunsaturated fatty acids in the membrane undergo peroxidation (Liu et al., 2012). Lipid peroxidation in plant is considered the best criterion for damage caused by increasing ROS production (Luo et al., 2010). However, cell membrane stability has been used as an efficient criterion of plant stress tolerance (Sairam et al., 2005).

In the present study, the application of validamycin A could markedly alleviate the lipid peroxidation caused by salt stress by increasing the accumulation of trehalose which lead to reducing the accumulation of leaf MDA contents and increasing the activities of antioxidant enzymes such as POD and CAT in both cultivars. The reduction in MDA contents could also have been due to the putative role of trehalose in alleviating the stress-induced deleterious effects on the structure of cell membranes and activities of different antioxidant

Egypt. J. Bot., Vol. 56, No. 1 (2016) 
enzymes as well as reducing the generation of highly destructive free radicals (Fernandez et al., 2010). For example, less oxidative damage was reported in trehalose treated plants in terms of reduced MDA contents and enhanced levels of enzymatic (SOD, POD, CAT) (Duman et al., 2010).

Furthermore, trehalose has been reported to be very effective in increasing lipid bilayer fluidity and in preserving enzyme stability in different cultivars of bean during drying (Ali and Ashraf, 2011).

The equilibrium between the ROS production rate and their scavenging rate by enzymatic and non enzymatic antioxidants will determine the degree of damage induced by ROS (Gill and Tuteja, 2010).

It was observed that the lower concentrations of salt $(50 \mathrm{mM}$ and $75 \mathrm{mM})$ resulted in an overall enhancement in the activities of most antioxidant enzymes, while it decreased at $100 \mathrm{mM}$ suggesting an inhibitory effect of $100 \mathrm{mM}$ on the enzyme activity. However, application of validamycin A caused an overall enhancement in the activities of all the enzymes under salt stress, suggesting the presence of an effective scavenging mechanism to remove ROS from the plant system and acting as a potential mechanism of plant salt tolerance.

SOD in particular, is the most effective intracellular enzyme mediating the removal of $\mathrm{O}^{2 \cdot-}$ radicals to $\mathrm{H}_{2} \mathrm{O}_{2}$ (Gill and Tuteja, 2010). The enhanced activity of this enzyme in AgamiM5 rice cultivar at $100 \mathrm{mM} \mathrm{NaCl}$ treatment and the concomitant decreased activity in Sakha103 cultivar implies that the first species had more efficient capacity for the removal of $\mathrm{O}^{2 \cdot-}$ radicals, thus reducing its oxidative damage and cellular toxicity than Sakha103 cultivar. Similar increases in the activities of SOD have been reported in faba bean (Hassanein et al., 2012), Oryza sativa (Nunkaewa et al., 2014). However, Tijen and İsmail (2005) found only a slight increase in the activity of SOD in roots of Pokkali (rice salttolerant) and a no-induced activity of SOD in the root of IR-28 (rice saltsensitive) under $120 \mathrm{mMNaCl}$ stress. Different alteration of SOD activity indicated the variation in the mechanisms of the conversion of $\mathrm{O}^{2 .-}$ to $\mathrm{H}_{2} \mathrm{O}_{2}$ under salt stress among crop species.

The utilization of multiple isoforms of antioxidant enzymes is one of the mechanisms involved in preventing the damage caused by ROS (Kim et al., 2005). Previous studies have indicated that $\mathrm{NaCl}$ stress can either stimulate or inhibit the expression of the isoforms of several antioxidant enzymes. The increase of constitutive isoforms in potato seedlings, new POD and SOD isoenzymes appeared in response to salt stress (Zhang et al., 2013).

Although the specific activity of each isoenzyme was not identified, the staining intensities of these isoenzymes showed a similar change trend compared to the changes assaying in total SOD activities. With the increase in total SOD activity, a concomitant increase in the activities of all the isoforms of SODs was observed in response to salt stress in both cultivars, although $\mathrm{Fe}-\mathrm{SOD}$ and $\mathrm{Cu}-$

Egypt. J. Bot., Vol. 56, No. 1 (2016) 
Zn-SOD were the predominant form suggesting that most of the SOD activity was due to this isoforms of the enzyme. A similar increase in SOD and its isoform has been observed in Brassica campestris and rice in salt stress by Hernández et al. (2010) and Turan and Tripathy (2013), respectively.

Increases in specific SOD isozyme abundance or total SOD activity have been observed in salt tolerant pea plants and opposite changes observed in salt sensitive varieties (Hernandez et al., 2000). Our results showed that SOD increased in both rice cultivars pretreated with validamycin A and subjected to salt stress and this is in accordance with Gómez et al. (2004) and Hu et al. (2012), who found an increase in all SOD isoenzymes of pea and perennial ryegrass plants respectively following $\mathrm{NaCl}$ treatment.

Hydrogen peroxide $\left(\mathrm{H}_{2} \mathrm{O}_{2}\right)$, a product of SOD activity, is toxic to cells and must be converted into $\mathrm{H}_{2} \mathrm{O}$ in subsequent reactions. As a result of CAT and APX activity, $\mathrm{H}_{2} \mathrm{O}_{2}$ is broken down to form water and oxygen (Zhang et al., 2007). In this study, CAT activity was found to increase in response to an initial increase in $\mathrm{NaCl}$ exposure in the first week. Results slightly decreased in the second week especially in Sakha103, while, Agami M5 showed a decrease in CAT activity at $100 \mathrm{Mm}$ in the second week only. This initial increase could be due to an increase in the amount of $\mathrm{H}_{2} \mathrm{O}_{2}$. The later decrease in activity of these enzymes may be caused by inactivation or degradation by peroxisomal protease (Duman et al., 2011). Similar results were obtained by Turan and Tripathy (2013) who showed that CAT activity was found to be increased in response to salt stress in both rice cultivars although its activity was decreased with time in stressed or unstressed conditions.

CAT activity was significantly increased by the application of exogenous validamycin A which consequently increased the plant trehalose content and this corroborate with the results of Ali and Ashraf (2011) who stated that trehalose has a simulative effect on CAT activity. In contrast, Luo et al. (2008) stated that trehalose has an adverse effect on CAT activity in wheat plant.

Also, APX plays a key role in scavenging $\mathrm{H}_{2} \mathrm{O}_{2}$ through ascorbateglutathione cycle in the cytosol and chloroplast and its enhanced activity has been associated with the tolerance to oxidative stress in various plant species (Ben Amor et al., 2006).

In the present study, both cultivars seems to be capable of quenching $\mathrm{H}_{2} \mathrm{O}_{2}$ by activating APX at all $\mathrm{NaCl}$ concentration after the first week of application, while in the second week the activity was diminished in Sakha103 at 75 and 100 $\mathrm{mM} \mathrm{NaCl}$ and also in Agami M5 at $100 \mathrm{mMNaCl}$ only, suggesting that the latter concentration was prone to excessive oxidative stress resulting in increased membrane permeability. Also, both rice cultivars treated with validamycin A with and without salt stress significantly increased the activity of APX, relating to much lower level of $\mathrm{H}_{2} \mathrm{O}_{2}$ compared to the non treated and treated corresponding salinity level. Our results are also supported by the results of

Egypt. J. Bot., Vol. 56, No. 1 (2016) 
Duman et al. (2011) who observed that trehalose application increased the APX activity. According to our results, trehalose plays an important role in the detoxification of $\mathrm{H}_{2} \mathrm{O}_{2}$. Moreover, Bae et al. (2005) and Aghdasi et al. (2008) suggested that the up-regulation of ROS responsive genes has been linked with trehalose concentration in Arabidopsis thaliana.

Glutathione reductase enzyme (GR) plays a central role in ROS detoxification in plants, particularly during salinity (Gill et al., 2013). Our results show that GR activity in leaves of Agami M5 cultivar salt-stressed plants was greater than control plants. On the other hand, salinity significantly reduced GR activity in Sakha103 cultivar at all $\mathrm{NaCl}$ concentrations except in $50 \mathrm{mM}$. Several authors have suggested that the salt tolerance cultivars is related to increased GR activity than in sensitive cultivars (Neto et al., 2006). In addition, both rice cultivars treated with validamycin A with and without salt stress significantly increased the activity of GR at all concentrations of salt stress. This result was correlated with Ma et al. (2013) who showed that GR activity increased by exogenous trehalose not only in the normal condition but also in the water deficit.

Peroxidases are involved not only in the conversion of $\mathrm{H}_{2} \mathrm{O}_{2}$ into water, but also in the oxidation of a wide variety of substrates (Cuypers et al. 2002). Our results indicated that $100 \mathrm{mMNaCl}$ caused greater POD activities of both cultivars subjected to short-term salt stress. However, the POD activity was higher in 'Agami M5' versus 'Sakha103', suggesting that tolerant cultivar had a greater protection against the oxidative stress. It has been shown that salt induced POD activity in plants adapted to $\mathrm{NaCl}$, especially in tolerant ones (Rahnama and Ebrahimzadeh, 2005).

The Agami M5 plants in the second week showed much lower activity in both stressed and unstressed plants in comparison to the first week plants; so, this activity was insufficient to prevent $\mathrm{H}_{2} \mathrm{O}_{2}$ accumulation. The lower leaf $\mathrm{H}_{2} \mathrm{O}_{2}$ concentration upon validamycin $\mathrm{A}$ application could be the reason for the activation of leaf POD activity compared to $\mathrm{NaCl}$ without validamycin A treated plants.

The expression patterns of the POD isoenzymes depend on different tissues or environmental stresses (Passardi et al., 2005). In this study, the POD isoforms showed different patterns in activities under short-term salt exposure in both genotypes. The changes in the staining intensities of the isoenzymes (POD5) showed a similar trend compared to the changes of POD activity in solutions. These results suggested that the increased POD activity could contribute to the antioxidant mechanism of Agami M5 against salt stress. Also, the fact that the highly concentrated POD-1 and POD-3 in both cultivars exhibited significant increases in their concentrations indicated that POD-1 and POD-3 are the most prominent and sensitive active isoforms of POD enzyme. POD-4 and POD-5 were only observed more intense at validamycin $A$ alone and plus $\mathrm{NaCl}$ concentrations in Agami M5 and these indicated that AgamiM5 was able to enhance its salt tolerance through increasing POD activities and numbers of 
isoforms. Gao et al. (2008) have also reported that high POD isozyme activity was detected in salt tolerant cultivar compared to salt susceptible cultivar of Jatropha curcas seedlings. The POD transcripts significantly increased with the increasing of salt exposure in salt-sensitive 'Sakha103' primed with validamycin A, which was not coincide with the POD isoenzyme activities. This is a lined with $\mathrm{Hu}$ et al. (2012) who suggested that stress mediated changes in the abundance of a particular transcript do not always correlate with corresponding changes in antioxidant protein levels and/or enzyme activities.

Polyphenol oxidase (PPO) plays a defensive role in plants against pathogens and abiotic stresses (Radhakrishnan and Lee, 2014). PPO is also a functional mediator of salt stress adaptation in plants (Barbieri et al., 2012). Kostopoulou et al. (2014) showed that the PPO activity was enhanced by $\mathrm{NaCl}$ treatment in citrus, whereas chemical treatments further stimulated its activity. In our study, PPO activity was enhanced gradually by increasing $\mathrm{NaCl}$ treatment in Agami M5 cultivar whereas validamycin A treatment further stimulated its activity. A similar increase in PPO activity in response to salinity stress has been found in bean (Demir and Kocaliskan, 2001). Recently, Rajaravindran and Natarajan (2012) suggested that the high PPO activity under stress indicates its ability to oxidize and to degrade the toxic substances such as phenolic compounds which are generally reported to be accumulated during salt stress. Moreover, treatment with validamycin A caused PPO activation and mitigated the salinity effect on both tested rice cultivars plants.

Native gel electrophoretic separation indicated that both rice cultivars expressed five isoforms PPO1, PPO 2, PPO 3, PPO 4 and PPO5. An increase in catalytic activity of PPO was accompanied with an increase in its isoforms in response to salinity. Most of the activity was due to isoforms PPO4 and PPO5. In Sakha103 cultivar isoforms PPO 4 and PPO 5 substantially reduced after $75 \mathrm{mM}$ $\mathrm{NaCl}$ application. However, isoform PPO4 and PPO5 is more pronounced in the salt-tolerance cultivar (Agami M5) after salt stress. These results are in correlated with El-Mashad and Mohamed (2012) who found that salinity stress induced two PPO bands in Vigna sinensis treated with 50, 100 and $150 \mathrm{mM}$ $\mathrm{NaCl}$ also El-Sayed et al. (2007) found that salinity stress induced two PPO bands in wheat Sakha 93 cultivar. Moreover, the induction of PPO isoforms was very intense in the validamycin $\mathrm{A}$ plus $\mathrm{NaCl}$ treatment compared to all other treatments.

Non-enzymatic secondary metabolites such as phenolics, tocopherols and ascorbic acid have well known antioxidative role in scavenging the ROS. In the present study, the contents of tocopherols and ascorbic acid increased, while those of phenolics decreased due to the application of validamycin A plus salt stress in both cultivars.

Phenolic compounds and flavonoids have important physiological role in the protection and development of plants and these compounds are affected by abiotic stresses (Edreva et al., 2008). Phenol accumulation could be a cellular

Egypt. J. Bot., Vol. 56, No. 1 (2016) 
adaptive mechanism for scavenging oxygen free radicals during stress (Mohamed and Aly, 2008). Several studies have reported that total phenol production is stimulated by $\mathrm{NaCl}$ (Navarro et al., 2006 and Hanen et al., 2008).

Results of our study showed that as salinity increases, accumulation of phenols increases in both cultivars and the magnitude of increase was at the salt tolerance Agami M5 cultivar. These results concur with the findings of Sonar et al. (2011) who reported increased contents of phenols in chickpea under salinity stress.

Flavonoids are frequently increased by abiotic stress and promote roles in plant protection (Sonar et al., 2011). These compounds accumulated in plant tissue could help to protect themselves from damaging effects by act as a free radical scavenger because the hydroxyl groups present in their structure. Data recorded in the Fig. 10 indicated that salt stress induced accumulated amount of total flavonoids in both cultivars with increasing salt stress and this increase was lowered in long term exposure to salt stress and the magnitude of increase was at salt-tolerant cultivar (Agami M5). Similar results were obtained by Chutipaijit et al. (2009) who reported that total flavonoids presented in the stressed seedling of salt-tolerant cultivar (rice) higher than those of salt-sensitive cultivar when compared to control. Also application of Validamycin A as seed soaking induced an additive stimulatory effect on the accumulation of total flavonoids content as compared with those of the corresponding salinity level. Trehalose causes an increase in total flavonoids contents, the results can be related to the findings of Ali et al. (2012), who reported that exogenous application of trehalose as a foliar spray further increased the contents of oil flavonoids in both maize cultivars under water stress regimes.

Ascorbic acid (ASA) has also been shown to play multiple roles in plant growth, such as in cell division, cell wall expansion, and other developmental processes (Pignocchi and Foyer, 2003). Although Senadheera et al. (2012) showed no significant reduction in ASA content in FL478 (rice salt tolerance), whereas IR29 (rice salt sensitive) showed a significant reduction in long term exposure to salt stress. Khan and Panda (2008) recorded the decrease in ASA content in the roots of both salt tolerant and susceptible varieties in response to short term salt stress. Similar results are also found in both tested rice cultivars in our study. Our results show that validamycin A in combination with salt stress showed more increase in ASA than the corresponding salinity level (Fig. 11). It has been shown that ASA minimizes the damage caused by oxidative process through synergic function with other antioxidants (Jaleel et al. 2009). The other functions of ASA includes, scavenging of $\mathrm{H}_{2} \mathrm{O}_{2}$ by ascorbate- glutathione cycle, elimination of ROS, and maintenance of $\alpha$ - tocopherol in reduced form (Mishra and Prakash, 2010).

$\alpha$ - Tocopherol (vitamin E) is known as natural antioxidant which interacts with the polyunsaturated acyl group of lipids that stabilizes the membranes. It also helps in scavenging and quenching of various ROS and lipid soluble byproducts of oxidative stress (Jaleel et al., 2009). The endogenous status of a-tocopherol is significantly

Egypt. J. Bot., Vol. 56, No. 1 (2016) 
modulated by environmental stresses and associated with the protection of plants against photo oxidative stress (Kostopoulou et al., 2014) and salinity (Queirós et al., 2011).

In Agami M5 cultivar, it was observed that the application of all concentrations of salt stress resulted in an enhancement in the activities of the $\alpha$-Tocopherol content, while in Sakha cultivar it was decreased at (75 $\mathrm{mM}$ and $100 \mathrm{mM}$ ) which might be due to the inhibition of tocopherol synthesis or activation of some enzyme which is involved in degradation of tocopherol. However, application of validamycin A caused an overall enhancement in the contents of $\alpha$-tocopherol under the effect of various concentrations of salt stress in both cultivars, suggesting that the presence of an effective scavenging mechanism to remove ROS from the plant system and acting as a potential mechanism of plant salt tolerance. This result was corroborated with Ali and Ashraf (2011) who observed that exogenous application of trehalose increased the leaf tocopherol contents of both maize cultivars.

However, exogenously applied validamycin A increased the contents of all these antioxidant compounds under stress conditions due to accumulation of trehalose. The increase in trehalose is negatively associated with leaf MDA and hydrogen peroxide contents, thus showing the role of this osmolyte in plant oxidative defense mechanism by increasing the accumulation of antioxidative secondary metabolites under stress conditions. Furthermore, less oxidative damage was reported in validamycin A treated plants by increasing nonenzymatic (flavonoids, ascorbic acid, and tocopherols) compounds.

\section{References}

Adly, A.A.M. (2010) Oxidative stress and disease: an updated review. Res. J. Immunol., 3,129-145.

Aebi, H. (1984) Catalase in vitro. Methods in Enzymology, 105, 121-126.

Aghdasi, M., Smeekens, S. and Schluepman, H. (2008) Microarray analysis of gene expression patterns in Arabidopsis seedlings under trehalose, sucrose and sorbitol treatment. Int. J. Plant Prod., 2, 309-320.

Ahmed, H.E., Elhusseiny, A.Y., Maimona, A.K. and Qaid, E.A. (2013) Trehalose accumulation in wheat plant promotes sucrose and starch biosynthesis. Jordan J. Biol. Sci., 6,143 -150.

Ali, Q. and Ashraf, M. (2011) Induction of drought tolerance in maize (Zea mays L.) due to exogenous application of trehalose: growth, photosynthesis, water relations and oxidative defence mechanism. J.Agron.and Crop Sci.,197, 258-271.

Ali, Q., Ashraf, M., Anwar, F. and Al-Qurainy, F. (2012) Trehalose-induced changes in seed oil composition and antioxidant potential of maize grown under drought stress. J. Am. Oil Chem. Soc., 89,1485-1493.

Egypt. J. Bot., Vol. 56, No. 1 (2016) 
Ashraf, A. (2011) Seed storage protein polymorphism in ten elite rice (Oryza sativa L.) genotypes of Sindh. Afr. J. Biotech., 10(7),1106-1111.

Backer, H., Frank, O., De Angelis, B. and Feingold, S. (1980) Plasma tocopherol in man at various times after ingesting free or acetylated tocopherol. Nutr. Rep. Int., 21, 531-536.

Bae, H., Herman, E., Bailey, B., Bae, H. J. and Sicher, R. (2005) Exogenous trehalose alters Arabidopsis transcripts involved in cell wall modification, abiotic stress, nitrogen metabolism and plant defense. Physiol. Plant., 125, 114-126.

Barbieri, G., Vallone, S., Orsini, F., Paradiso, R., De Pascale ,S., Negre-Zakharov, F. and Maggio, A. (2012) Stomatal density and metabolic determinants mediate salt stress adaptation and water use efficiency in basil (Ocimum basilicum L.). J. Plant Physiol., 169, 1737-1746.

Beauchamp, C. and Fridovich, I. (1971) Superoxide dismutase: improved assays and an assay applicable to acrylamide gels. Anal Biochem., 44, 276-87.

BenAmor, N., Jiménez, A., Megdiche, W., Lundqvist, M., Sevilla, F. and Abdelly, C. (2006) Response of antioxidant systems to $\mathrm{NaCl}$ stress in the halophyte Cakile maritima. Physiol. Plant., 126, 446-457.

Best, M., Koenig, K., McDonald, K., Schueller, M., Rogers, A. and Ferrieri, R.A. (2011) Inhibition of trehalose breakdown increases new carbon partitioning into cellulosic biomass in Nicotianatabacum. Carbohydrate Res., 120, 346, 595-601.

Chang, B. W., Cong, W. W., Chen, Q., Zu, Y.G. and Tang, Z. H. (2014a) The influence of different forms and concentrations of potassium nutrition on growth and alkaloid metabolism in Catharanthusroseus seedlings. J. Plant Interact., (9), 370-377.

Chang, B., Yang, L., Cong, W., Zu, Y. and Tang, Z. (2014b) The improved resistance to high salinity induced by trehalose is associated with ionic regulation and osmotic adjustment in Catharanthusroseus. Plant Physiology and Biochemistry, (77) 140-148.

Cheeseman, J.M. (2007) Hydrogen peroxide and plant stress: a challenging relationship. Plant Stress, 1:4-15.

Chutipaijit, S., Cha-Um, S. and Sompornpailin, K. (2009) Differential accumulations of proline and flavonoids in Indica rice Varieties against salinity. Pak. J. Bot., 41(5), 2497-2506.

Cuypers, A., Vangronsveld, J. and Clijsters, H. (2002) Peroxidases in roots and primary leaves of Phaseolus vulgaris copper and zinc phytotoxicity: a comparison. $J$. Plant Physiol., 159(8), 869-876.

Demir, Y. and Kocaliskan, I. (2001) Effects of $\mathrm{NaCl}$ and proline on polyphenol oxidase activity in bean seedlings. Biol. Plant., 44, 607-609.

Duman, F., A. Aksoy, Z. Aydin and Temizgul, R. (2010) Effects of exogenous glycine betaine and trehalose on cadmium accumulation and biological responses of an aquatic plant (Lemnagibba L.). Water Air Soil Pollut. DOI 10.1007/ s11270-0100608-5.

Egypt. J. Bot., Vol. 56, No. 1 (2016) 
Duman, F., A. Aksoy, Z. Aydin and Temizgul, R. (2011) Effects of Exogenous Glycinebetaine and Trehalose on Cadmium Accumulation and Biological Responses of an Aquatic Plant (Lemna gibba L.). Water Air Soil Pollut. (217), 545-556.

Eastmond, P.J. and Graham, I.A. (2003). Trehalose metabolism: a regulatory role for trehalose-6-phosphate? Curr. Opin. Plant Biol., 6, 231-235.

Edreva, A., Velikova, V., Tsonev, T., Dagnon, S., Güre, A., Aktas, l. and Gesheva, E. (2008) Stress-protective role of secondary metabolites: diversity of functions and mechanisms. Gen. Appl. Plant Physiol., 34, 67-78.

El-Mashad, A. A. A. and Mohamed, H. I. (2012) Brassinolide alleviates salt stress and increases antioxidant activity of cowpea plants (Vigna sinensis). Protoplasma, (249), 625-635.

El-Sayed, O.E., Rizkalla, A.A. and Sabri, S.R.S. (2007) In vitro mutagenesis for Genetic improvement of salinity tolerance in wheat. Res. J. Agri. Biol. Sci., 4(5), 377-3834.

Fernandez, J. M. G., Mellet, C.O., Blanco, J.L.J., Mota, J.F., Gadelle, A., Sarguet, A.C. and Defaye, J. (2010) Isothiocyanates and Cyclic Thiocarbamates of $\alpha, \alpha^{\prime}$ Trehalose, Sucrose and Cyclomalto oligosaccharides. Cheminform, 26 (28), DOI: 10.1002/chin.199528236.

Gao, S., Ouyang, C., Wang, S., Xu, Y., Tang, L. and Chen, F. (2008) Effects of salt stress on growth, antioxidant enzyme and phenylalanine and phenylalanine ammonialyase activities in Jatrophacurcas L. seedlings. Plant Soil Environ., (54), 374-81.

Giannopolitis, C.N., and Ries, S.K. (1977) Superoxide dismutases: II. Purification and quantitative relationship with water soluble protein in seedlings. Plant Physiol., 59, 315-318.

Gill, S.S. and Tuteja, N. (2010) Reactive oxygen species and antioxidantmachinery in abiotic stress tolerance in crop plants. Plant Physiol. Biochem., 48, 909-930.

Gill, S.S., Anjum, N.A., Hasanuzzaman, M., Gill, R., Trivedi, D.K., Ahmad, I., Pereira, E. and Tuteja, N. (2013) Glutathione and glutathione reductase: a boon in disguise for plant abiotic stress defense operations. Plant Physiol. Biochem.,70, 204-212.

Gomez, J.M., Jimenez, A., Olmos, E. and Sevilla, F. (2004) Location and effects of long-term $\mathrm{NaCl}$ stress on superoxide dismutase and ascorbate peroxidase isoenzymes of pea (Pisumsativum cv. Puget) chloroplasts. J. Exp. Bot., 55,119-30.

Hames, B.D. (1990) One-dimensional polyacrylamide gel electrophoresis. In "Gel Electrophoresis of Proteins: A practical approach", $2^{\text {nd }}$ ed (Ed. B.D. Hames and D. Rickwood). Oxford University Press, New York.

Hanen, F., Ksouri, R., Megdiche, W., Trabelsi, N., Boulaaba, M. and Abdelly, C. (2008) Effect of salinity on growth, leaf phenolic content and antioxidant scavenging activity in Cynaracardunculus L. Biosaline Agriculture and High Salinity Tolerance. Abdelli C, Ozturk M, Ashraf M, Grignon YC, (Eds.). BirkhauserVerlag, Switzerland, 335-343. 
Hassanein, R. A., Hashem, H.A. and Khalil, R.R. (2012) Stigmasterol treatment increases salt stress tolerance of faba bean plants by enhancing antioxidant systems. Plant Omics Journal, 5(5), 476-485.

Heath, R.L. and Packer, L. (1968) Photo peroxidation in isolated chloroplasts kinetics and stoichemistry of fatty acid peroxidation. Arch. Biochem. Biophys., (125),189-98.

Hernández, J., Jimenez, A. Mullineaux, P. and Sevilla, F. (2000) Tolerance of pea plants (Pisumsativum) to long term salt stress is associated with induction of antioxidant defences. Plant Cell Environ., 23, 853-862.

Hernandez, M., Fernandez-Garcia N., Diaz-Vivancos P. and Olmos, E. (2010) A different role for hydrogen peroxide and the antioxidative system under short and long salt stress in Brassica oleracea roots. J. Exp. Bot., 61, 521-35.

Hodges, D.M, Andrews, C.J, Johnson, D.A. and Hamilton, R.I. (1997) Antioxidant enzyme responses to chilling stress in differentially sensitive inbred maize lines. $J$. Exp Bot., 48, 1105-13.

Hu, L., Li, H, Pang, H. and Fu, J. (2012) Responses of antioxidant gene, protein and enzymes to salinity stress in two genotypes of perennial ryegrass (Loliumperenne) differing in salt tolerance. J. Plant Physiol., 169, 146- 156.

Jagota, S.K. and Dani, H.M. (1982) A new colorimetric technique for the estimation of vitamin C using Folin phenol reagent. Anal Biochem., 127, 178-82.

Jaleel, C.A., Riadh, K., Gopi, R., Manivannan, P., Ines J., Al-Juburi, H.J., Zhao C.X., Shao H.B. and Panneerselvam R. (2009) Antioxidant defense response: physiological plasticity in higher plants under abiotic constraints. Acta Physiol. Plant., 31, 427-436.

Julkenen-Titto, R. (1985) Phenolic constituents in the leaves of northern willows: methods for the analysis of certain phenolics. Agric. Food Chem. (33), 213-217.

Khan, M. H. and Panda, S. K. (2008) Alterations in root lipid peroxidation and antioxidative responses in two rice cultivars under $\mathrm{NaCl}$ salinity stress. Acta Physiol. Plant., 30, 81-89.

Kim, S.Y., Lim, J.H., Park, M.R., Kim, Y.J., Park ,T.I. and Seo, Y.W. (2005) Enhanced antioxidant enzymes are associated with reduced hydrogen peroxide in barley roots under saline stress peroxide in barley roots under saline stress. J. Biochem Mol. Biol., (38), 218-24.

Kostopoulou, Z., Therios I. and Molassiotis A. (2014) Resveratrol and its combination with a-tocopherol mediate salt adaptation in citrus seedlings. Plant Physiol. and Bioch., (78), 1- 9.

Laemmli, U.K. (1970) Cleavage of structural proteins during the assembly of the head of bacteriophage T4. Nature, 227, 680- 685 .

Lee, H. S. and Wicker, L. (1991) Anthocyanin pigments in the skin of lychee fruit. Journal of Food Sci., 56(2), 466-468, 483. 
Lee, M. H., Cho, E. J., Wi, S. G., Bae, H., Kim, J. E., Cho, J. Y., Lee, S., Kim, J. H. and Chung, B. Y. (2013) Divergences in morphological changes and antioxidant responses in salt-tolerant and salt-sensitive rice seedlings after salt stress. Plant Physiol. and Bioch., (70), 325-335.

Liu, X., Chi, H., Yue, M., Zhang, X.F., Li, W.J., and Jia, E.P. (2012) The regulation of exogenous jasmonic acid on UV-B stress tolerance in wheat. J. Plant Growth Regul., 31,436-447.

Lo'pez, M., Tejera, N.A. and Lluch, C. (2009) Validamycin A improves the response of Medicagotruncatula plants to salt stress by inducing trehalose accumulation in the root nodules. J. Plant Physiol., 166, 1218-1222.

Luo, Y., Li, F., Wang, G. P., Yang, X. H. and Wang, W. (2010) Exogenously-supplied trehalose protects thylakoid membranes of winter wheat from heat-induced damage. Biol. Plant, 54, 495-501.

Luo, Y., Li W. and Wang, W. (2008) Trehalose: Protector of antioxidant enzymes or reactive oxygen species scavenger under heat stress. Env. and Exp. Botany, 63, 378-384.

Ma, C., Wang, Z., Kong, B. and Lin, T. (2013) Exogenous trehalose differentially modulate antioxidant defense system in wheat callus during water deficit and subsequent Recovery. Plant Growth Regul., 70, 275-285.

Malik, S., Nayak, M., Sahu, B.B., Panigrahi, A.K. and Shaw, B.P. (2011) Response of antioxidant enzymes to high $\mathrm{NaCl}$ concentration in different salt-tolerant plants. Biol. Plant., 55, 191-195.

Mansour, M.M.F. (2013) Plasma membrane permeability as an indicator of salt tolerance in plants. Biologia Plant Arum., 57 (1), 1-10.

Mishra, M.K. and Prakash, V. (2010) Response of non-enzymatic antioxidants to zinc induced stress at different $\mathrm{pH}$ in Glycine max L. cv. Merrill. Acad. J. Plant Sci., 1, 1-10.

Mohamed, A.A and Aly, A.A. (2008) Alternations of some secondary metabolites and enzymes activity by using exogenous antioxidant compound in onion plants grown under seawater salt stress. American-Eurasian J. Sci. Res., 3, 139-146.

Morsy, M.R., Jouve, L., Hausman, J.F., Hoffmann, L. and Stewart, J.D. (2007) Alteration of oxidative and carbohydrate metabolism under abiotic stress in two rice (Oryza sativa L.) genotypes contrasting in chilling tolerance. J. Plant Physiol., 164, 157-167.

Navarro, J.M., Flores, P., Garrido, C. and Martinez, V. (2006) Changes in the contents of antioxidant compounds in pepper fruits at ripening stages, as affected by salinity. Food Chem., 96, 66-73.

Neto, A. D. d., Prisco, J. T., Filho, J. E., de Abreu, C. E. B. and Filho, E. G. (2006) Effect of salt stress on antioxidative enzymes and lipid peroxidation in leaves and roots of salt-tolerant and salt-sensitive maize genotypes. Environ. and Experim. Botany, 56, 87-94. 
Nunkaewa, T., Kantachote, D., Kanzaki, H., Nitoda, T. and Ritchie, R. J. (2014) Effects of 5-aminolevulinic acid (ALA)-containing supernatants from selected Rhodopseudomon aspalustris strains on rice growth under $\mathrm{NaCl}$ stress, with mediating effects on chlorophyll, photosynthetic electron transport and antioxidative enzymes. Electronic J. Biotechn., (17), 19-26.

Passardi, F., Cosio, C., Penel, C. and Dunand, C. (2005) Peroxidases have more functions than a Swiss army knife. Plant Cell Rep., 24, 255-265.

Paul, M. (2007) Trehalose 6-phosphate. Curr.Opin. Plant Biol., 10, 303-309.

Paul, M.J., Primavesi, L.F., Jhurreea, D. and Zhang, Y. (2008) Trehalose metabolism and signalling. Annu. Rev. Plant Biol., 59, 417-441.

Pignocchi, C. and Foyer, C.H. (2003) Apoplasticascorbate metabolism and its role in the regulation of cell signaling. Current Opinion in Plant Biology, 6, 379-389.

Queirós, F., Rodrigues, J.A., Almeida, J.M., Almeida, D.P.F. and Fidalgo, F. (2011) Differential responses of the antioxidant defence system and ultra structure in a salt adapted potato cell line. Plant Physiol. Biochem., 49, 1410-1419.

Radhakrishnan, R. and Lee, I. J. (2014) Effect of Low Dose of Spermidine on Physiological Changes in Salt Stressed Cucumber Plants. Russian Journal of Plant Physiology., 61 (1) 90-96.

Rahnama, H. and Ebrahimzadeh, H. (2005) The effect of $\mathrm{NaCl}$ on antioxidant enzyme activities in potato seedlings. Biol. Plant., 49, 93-97.

Rajaravindran, M. and Natarajan, S. (2012) Effects of salinity stress on growth and biochemical constituents of the halophyte Sesuvium portulacastrum. Intern. J. Res. Biol. Sci., 2 (1), 18-25.

Sairam, R.K., Srivastava G.C., Agarwal S. and Meena R.C. (2005) Differences in antioxidant activity in response to salinity stress in tolerant and susceptible wheat genotypes. Biol. Plant., (49), 85-91.

Sawada, H., Shim I.S. and K. Usui (2006) Induction of benzoic acid 2-hydroxylase and salicylic acid biosynthesis-Modulation by salt stress in rice seedlings. Plant Sci., 171, 263-270.

Schluepmann, H. and Paul, M. (2009) Trehalose Metabolites in Arabidopsis-elusive, active and central. American Society of Plant Biologists, The Arabidopsis Book, 1- 17.

Senadheera, P., Tirimanne, S. and Maathuis, F. J. M. (2012) Long term salinity stress reveals Variety Specific Differences in root oxidative stress response. Rice Sci., 19(1), $36-43$.

Sergiev, I., Alexieva, V. and Karanov, E. (1997) Effect of spermine, atrazine and combination between them on some endogenous protective systems and stress markers in plants. C R Acad. Bulg. Sci., 51, 121-124. 
Silvana, B.D., Susana, M.G., Marria, P.B. and Maria, L.T. (2003) Behavior of antioxidant defense system in the adaptive response to salt stress in Helianthus annus L. Cells. Plant Growth Regul., (49), 81- 88.

Snedecor, G. M. and Cochran, W. C. (1969) "Statistical methods". $6^{\text {th }} e d$. Iowa Univ. press. Ames. Iowa U.S.A.

Sonar, B.A., Desai, Nivas, M., Gaikwad, D.K. and Chavan, P.D. (2011) Assessment of Salinity-Induced Antioxidative Defense System in Colubrina asiatica Brong. J. Stress Physiol. and Bioch., 7 (3),193-200.

Tijen, D. and İsmail, T. (2005) Comparative lipid peroxidation, antioxidant defense systems and praline content in roots of two rice cultivars differing in salt tolerance. Environ. and Experim. Botany, 53, 247-257.

Tsai, Y., Hong, C., Liu, L. and Kao, C. (2004) Relative importance of $\mathrm{Na}+$ and $\mathrm{Cl}-$ in $\mathrm{NaCl}$ induced antioxidant systems in roots of rice seedlings. Physiol, Plant., (122), 86-94.

Turan, S. and Tripathy, B.C. (2013) Salt and genotype impact on antioxidative enzymes and lipid peroxidation in two rice cultivars during de-etiolation. Protoplasma, 250 (1), 209-222.

Yamunarani, K., Jaganathan, R., Bhaskaran, R., Govindaraju, P. and Velazhahan, R. (2004) Induction of early blight resistance in tomato by Quercusinfectoria gall extract in association with accumulation of phenolics and defense-related enzymes. Acta Physiol. Plant, 26(3), 281-290.

Yingsanga, P., Srilaong, V., Kanlayanarat, S., Noichinda, S. and McGlasson, W.B. (2008) Relationship between browning and related enzymes (PAL, PPO and POD) in rambutan fruit (Nephelium lappaceum Linn.) cvs. Rongrien and See-Chompoo. Postharvest Biology and Techno., 50, 164-168.

Yong, S. P., Soon T. J., Seong G. K., Buk G. H., Patricia A. A. and Fernando T. (2008) Antioxidants and proteins in ethylene-treated kiwifruits. Food Chem., 107(2), 640-648.

Zhang, L. X., Li, S. X., Zhang, H. and Liang, Z. S. (2007) Nitrogen rates and water stress effects on production, lipid peroxidation and antioxidative enzyme activities in two maize (Zea mays L.) genotypes. J. Agron. Crop Sci., 193, 387-397.

Zhang, M., Fang, Y., Ji, Y., Jiang, Z. and Wang, L. (2013) Effects of salt stress on ion content, antioxidant enzymes and protein profile in different tissues of Broussonetia papyrifera. South African J. Botany, 85, 1-9. 


\section{بعض جوانب صفات مضادات الأكسدة فى الأرز تحت اجهاد الملوحة مع المعالجة بالفاليداميسن}

سامية محب الخلال " وزينب أحمد عبد الجواد و "تهانى عباس حتحوت "وإجلال

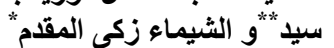

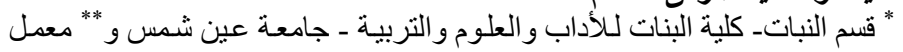

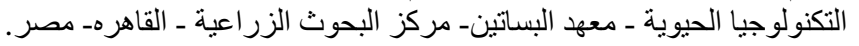

تعد معالجة بذور النباتات قبل الزر اعة استر اتيجية قيمة لتحفيز دفاعات النبات، ممـا

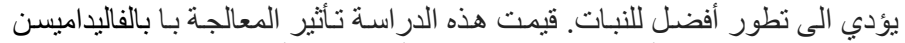

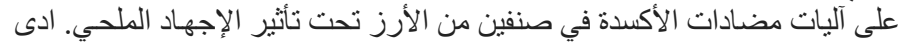

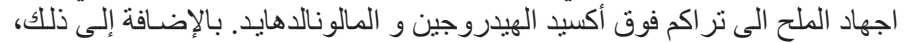

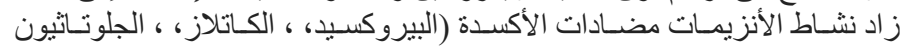

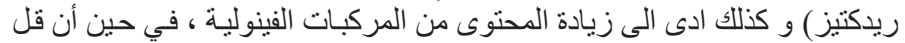

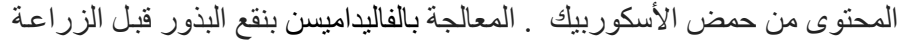

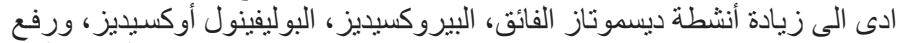

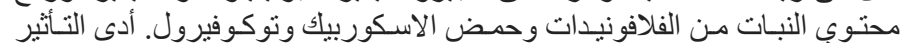

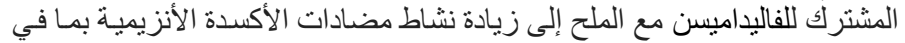

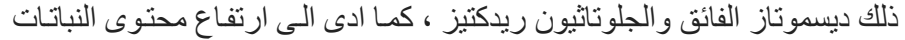

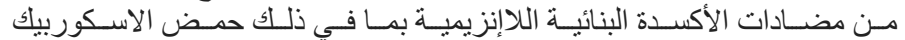

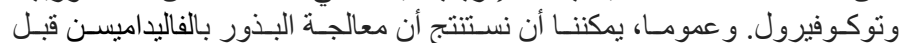

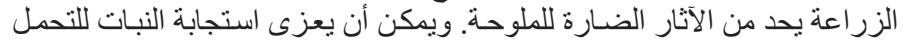
إلى قدرة فاليداميسن ألف على تحفيز الدفاعات المضادة للفئ للأكسدة. 